\title{
ANALISIS KESALAHAN PENYELESAIAN SOAL URAIAN MATEMATIKA SISWA MTS PADA POKOK BAHASAN UNSUR-UNSUR LINGKARAN
}

\author{
${ }^{1}$ Agita Apriliawan, ${ }^{2}$ Sardulo Gembong, ${ }^{3}$ Sanusi \\ ${ }^{1}$ Mahasiswa Prodi Matematika IKIP PGRI Madiun \\ ${ }^{2}$ Dosen Prodi Matematika IKIP PGRI Madiun \\ ${ }^{3}$ Dosen Prodi Matematika IKIP PGRI Madiun
}

\begin{abstract}
Abstrak. Penelitian ini bertujuan untuk mengidentifikasi kesalahan-kesalahan yang dilakukan siswa dalam menyelesaikan soal uraian pokok bahasan unsur-unsur lingkaran.Jenis penelitian yang digunakan adalah penelitian kualitatif deskriptif karena penelitian mengarah pada pendeskripsian secara rinci dan mendalam mengenai potret kondisi tentang apa yang sebenarnya terjadi dilapangan. Dalam penelitian ini dipilih subyek sebanyak 6 siswa MTs Negeri Caruban. Subyek dipilih berdasarkan rekomendeasi guru mata pelajaran matematika dengan kriteria 2 siswa dengan kemampuan matematika tinggi, 2 siswa dengan kemampuan matematika sedang, dan 2 siswa dengan kemampuan matematika rendah.Teknik pengumpulan data yang digunakan adalah metode tes dan wawancara. Tes digunakan untuk menganalisis kesalahan siswa dalam menyelesaikan masalah matematika pokok bahasan unsur-unsur lingkaran, sedangkan wawancara digunakan untuk menelusuri kesalahan yang dilakukan siswa secara lebih mendalam. Teknik keabsahan data yang digunakan adalah triangulasi sumber atau triangulasi data. Triangulasi ini mengarahkan peneliti agar di dalam mengumpulkan data, peneliti wajib menggunakan beragam sumber data yang tersedia. Sumber data yang digunakan adalah data hasil tes, dan data hasil wawancara.

Dari hasil tes dan wawancara maka dapat disimpulkan bahwa 1) kesalahan dalam menginterprestasi bahasa yang dilakukan siswa MTs kelas VIII adalah a) siswa dengan kemampuan matematika tinggi dan rendah cenderung tidak mengalami kesalahan dalam memahami maksud soal. b) siswa dengan kemampuan matematika tinggi dan rendah cenderung tidak mengalami kesalahan dalam menerjemahkan soal dari bahasa umum ke model matematika. 2) kesalahan konsep yang dilakukan siswa MTs kelas VIII adalah a) siswa dengan kemampuan matematika tinggi dan sedang cenderung tidak mengalami kesalahan dalam menerapkan konsep. b) siswa dengan kemampuan matematika tinggi dan sedang cenderung tidak mengalami kesalahan dalam dalam menerapkan rumus. c) siswa dengan kemampuan matematika rendah cenderung mengalami kesalahan dalam menentukan prosedur pengerjaan soal. 3) kesalahan teknis yang dilakukan siswa MTs kelas VIII adalah a) siswa dengan kemampuan matematika tinggi dan sedang cenderung tidak mengalami kesalahan dalam melakukan operasi hitung. 4) kesalahan kealpaan yang dilakukan siswa MTs kelas VIII adalah a) siswa dengan kemampuan matematika rendah cenderung mengalami kesalahan dalam menyelesaikan soal. b) Siswa dengan kemampuan matematika tinggi cenderung tidak mengalami kesalahan dalam kecermatan meneliti hasil pekerjaannya.
\end{abstract}

Kata Kunci : Analisis, Kesalahan Siswa, Unsur-Unsur Lingkaran

\section{PENDAHULUAN}

\begin{tabular}{lrrr}
\multicolumn{3}{c}{ Perkembangan } & ilmu \\
pengetahuan dan teknologi & yang \\
semakin pesat dewasa & ini
\end{tabular}
mengakibatkan suatu perubahan di berbagai bidang, tak terkecuali bidang pendidikan. Pendidikan merupakan instrumen yang amat penting bagi setiap bangsa untuk meningkatkan daya saingnya dalam persaingan ekonomi, hukum, budaya dan pertahanan pada tata kehidupan masyarakat dunia global.
Sadar akan hal itu, negara maju sekalipun selalu membangun dunia pendidikannya tanpa henti-hentinya. Hal ini terjadi karena peningkatan daya saing suatu negara memerlukan kualitas sumber daya manusia yang prima. Untuk itu, inovasi dibidang pendidikan sangat diperlukan agar kualitas pendidikan terus meningkat dan hasilnya sesuai dengan kemajuan masyarakat dan tuntutan jaman.Pendidikan di Indonesia, salah satunya pendidikan matematika 
memiliki peran yang sangat penting, karena matematika adalah ilmu dasar yang digunakan secara luas dalam berbagai bidang kehidupan. Melalui pembelajaran matematika siswa diharapkan dapat menumbuhkan kemampuan berpikir kritis, logis, sistematis, cermat, efektif, dan efisien dalam memecahkan masalah. Tercapai atau tidaknya tujuan pendidikan dan pembelajaran matematika salah satunya dapat dinilai dari keberhasilan siswa dalam menyelesaikan persoalan matematika maupun ilmu-ilmu yang lain. Untuk itu, perlu dilakukan evaluasi hasil belajar siswa. Dari hasil belajar ini dapat diketahui prestasi belajar siswa.

$$
\text { "Prestasi belajar }
$$

matematika adalah sebuah kecakapan atau keberhasilan yang diperoleh seseorang setelah seseorang tersebut belajar matematika baik pada aspek kognitif, afektif, maupun psikomotoriknya sesuai dengan kompetensi meteri pokok bahasan matematika yang dipelajari"(Darmadi, 2009:100). Akan tetapi, pada kenyataannya prestasi belajar matematika siswa masih rendah. Rendahnya prestasi belajar matematika ini ditunjukkan antara lain dengan rendahnya nilai ulangan harian, ulangan semester, maupun Ujian Akhir Nasional (UAN). Dari hasil observasi selama Praktek Pengalaman Lapangan (PPL) pada 7 september sampai dengan 3 desember 2012 di MTs Negeri Caruban, nilai ulangan harian terendah siswa Madrasah Tsanawiyah (MTs) Negeri Caruban, kelas VIII tahun pelajaran 2012/2013 terletak pada pelajaran matematika, hal ini menjadi salah satu masalah yang dihadapi sekolah.Banyak faktor yang mungkin menyebabkan rendahnya kemampuan matematika siswa. Faktor-faktor tersebut dapat berasal dari dalam atau dari luar diri siswa. Faktor dari dalam diri siswa dapat berupa motivasi, kemampuan intelektual siswa, minat, bakat, dan lain sebagainya.
Faktor dari luar, prestasi belajar siswa dapat dipengaruhi dari kondisi lingkungan keluarga, guru, teman, alat belajar dan sebagainya.Salah satu kemampuan yang dianggap rendah menurut guru dan kebanyakan siswa adalah kemampuan dalam menyelesaikan soal matematika yang berbentuk uraian. Soal uraian memang jarang digunakan, karena hanya digunakan untuk mengevaluasi pemahaman siswa saja setelah pemberian materi, ditambah ujian nasional pun bentuk soalnya berbentuk pilihan ganda, sehingga soal uraian jarang digunakan pada evaluasi pembelajaran matematika, maka tidak heran kalau kesalahan konsep dalam menyelesaikan soal uraian sering terjadi. Penelitian ini penting dilakukan terhadap siswa, karena untuk mengetahui sejauh mana tingkat kemampuan siswa dalam menyelesaikan soal uraian pada bidang studi matematika. Selain itu, guru juga dapat mengidentifikasi apa yang menyebabkan siswa melakukan kesalahan dalam menyelesaikan soal uraian pada bidang studi matematika.

Berdasarkan latar belakang di atas, maka rumusan masalah yang akan diajukan dalam penelitian ini adalah:

"Kesalahan apa saja yang dilakukan siswa dalam menyelesaikan soal uraian pokok bahasan Unsur-Unsur Lingkaran?"

Berdasarkan rumusan masalah di atas, maka tujuan yang ingin dicapai penulis adalah mengidentifikasi kesalahan-kesalahan yang dilakukan siswa dalam menyelesaikan soal uraian pokok bahasan Unsur-Unsur Lingkaran.

\section{PEMBAHASAN}

\section{Kajian Pustaka}

Pembelajaran di sekolah tidak selalu berhasil dalam mencapai tujuan. Hal ini disebabkan seperti yang 
disebutkan sebelumnya ada beberapa faktor internal dan ekternal dari siswa, begitu pula dalam belajar matematika banyak siswa yang merasa kesulitan dalam menyelesaikan suatu soal, sehingga siswa sering menganggap matematika adalah salah satu mata pelajaran yang sulit untuk dipelajari. Kesulitan belajar matematika disebut juga diskalkulia (dyscalculis). Istilah diskalkulia memiliki konotasi medis, yang memandang adanya keterkaitan dengan gangguan sistem saraf pusat. Menurut Lerner (dalam Mulyono Abdurrahman, 2012:210) ada beberapa karakteristik anak berkesulitan belajar matematika, yaitu (1) adanya gangguan dalam hubungan keruangan, abnormalitas perpsepsi visual, (3) asosiasi visual-motor, (4) perseverasi, (5) kesulitan mengenal dan memahami simbol, (6) gangguan penghayatan tubuh, (7) kesulitan dalam bahasa dan membaca, dan (8) Perfomance $I Q$ jauh lebih rendah daripada sekor Verbal IQ. Faktor-faktor yang mempengaruhi prestasi belajar dibedakan menjadi dua kategori yaitu faktor internal dan faktor eksternal. Kedua faktor tersebut saling mempengaruhi dalam proses belajar individu. Menurut Muhibbin Syah (dalam Syaiful Bahri, 2002:201) penyebab siswa kesulitan belajar terjadi karena beberapa faktor yang meliputi gangguan atau kekurangmampuan psiko-fisik siswa, yakni: (1) Bersifat kognitif (ranah cipta), antara lain seperti rendahnya kapasitas intelektual/intelegensi siswa, (2) Bersifat afektif (ranah rasa), antara lain seperti labilnya emosi dan sikap, (3) Bersifat psikomotor (ranah karsa), antara lain seperti terganggunya alat-alat indra penglihatan dan pendengaran (mata dan telinga).Menurut Muhibbin Syah (2009:184) secara garis besar, penyebab kesulitan belajar terdiri atas dua macam, yakni 1) Faktor intern siswa, yakni halhal atau keadaan-keadaan yang muncul dari dalam diri siswa. 2) Faktor ekstern siswa, yakni hal-hal atau keadaankeadaan yang datang dari luar diri siswa. Selain faktor-faktor yang bersifat umum di atas, ada pula faktor-faktor lain yang juga menimbulkan kesulitan belajar siswa. Di antara faktor-faktor dapat dipandang sebagai faktor khususu ini ialah sindrom psikologis berupa learning disability (ketidakmampuan belajar).

Kesalahan dan kekeliruan pada dasarnya adalah penyimpangan. Namun kedua hal itu berbeda jika dilihat dari penyebabnya. Kesalahan terjadi karena penyimpangan atas hal yang telah diketahui sebelumnya, sedangkan kekeliruan terjadi karena kesalahan dalam penafsirannya. Tipe-tipe kesalahan yang dilakukan siswa dalam menyelesaikan masalah matematika diklasifikasikan sebagai berikut: (a) Kesalahan menginterprestasi bahasa, tipe ini mencangkup kesalahankesalahan dalam memahami maksud soal, kesalahan dalam menerjemahkan dari bahasa umum ke model matematika. Kesalahan pemahaman meliputi ketidakpahaman siswa terhadap permintaan soal dan kurangnya pemahaman tentang simbol-simbol yang digunakan dalam menyelesaikan soalsoal matematika. Yang dimaksud kurang paham terhadap permintaan soal adalah siswa tidak tahu yang akan dia dikerjakan setelah dia memperoleh informasi dari soal namun terkadang siswa juga tidak tahu apa informasi yang berguna dari soal karena terjadi salah penafsiran. (b) Kesalahan konsep, tipe kesalahan ini adalah kesalahan yang dilakukan siswa dalam menerapkan konsep-konsep, rumus-rumus yang diperlukan untuk menjawab masalah, dan prosedur pengerjaan penyelesaian masalah. (c) Kesalahan teknis adalah kesalahan dalam melakukan operasi aljabar dan kesalahan perhitungan (penjumlahan, pengurangan, perkalian, dan pembagian). Proses pengoperasian yang keliru ini seperti mempertukarkan 
simbol-simbol, jumlah satuan dan puluhan ditulis tanpa memperhatikan nilai tempat, semua angka ditambahkan bersama (algoritma yang keliru dan tidak memperhatikan nilai tempat), angka-angka ditambahkan dari kiri ke kanan dan tidak memperhatikan nilai tempat, penambahan nilai puluhan yang digabungkan dengan nilai satuan, angka yang besar dikurangi angka yang kecil tanpa memperhatikan nilai tempat, dan angka yang telah dipinjam nilainya tetap. (d) Kesalahan kealpaan, meliputi kesalahan dalam menyelesaikan jawaban sampai akhir sesuai permintaan soal, ketidakcermatan dalam meneliti jawaban siswa.

Menyelesaikan masalah matematika adalah usaha mencari jalan keluar dari suatu permasalahan untuk mencapai suatu tujuan atau penyelesaian dari suatu permasalahan matematika. Penyelesaian masalah, secara sederhana tersebut merupakan proses-proses penerimaan masalah sebagai tantangan untuk menyelesaikan masalah. Menurut polya langkah-langkah dalam pemecahan masalah sebagai berikut 1) Memahami Masalah (Undestanding The Problem ). Langkah pertama adalah membaca soal dan memahaminya dengan benar. 2) Merencanakan Penyelesaian (Devising a Plant). Untuk memudahkan merencanakan penyelesaian masalah yaitu dengan membagi masalah ke dalam sub masalah. Langkah-langkah dalam membagi masalah ke dalam sub masalah sebagai berikut : (a) Membuat sub masalah pada masalah yang kompleks. (b) Menghubungkan masalah dengan hal sebelumnya yang sudah diketahui. (c) Mengenali pola pemecahan masalah tersebut. (d) Menggunakan analog dari masalah tersebut. (e) Asumsikan jawaban. 3)Melaksanakan Rencana (Carrying Out The Plant). Dalam melakaksanakan rencana pada langkah kedua, kita harus memeriksa tiap langkah dalam rencana dan menuliskan secara detail untuk memastikan tiap langkah sudah benar. 4) Memeriksa Proses Dan Hasil (Looking Back). Kritisi lagi hasil dari pemecahan masalah tersebut dan melihat kelemahankelemahan solusi dari masalah tersebut. (Ahmad Firdaus. http://krizi.wordpress.com/2011/09/12/ makalah-matematika-langkah-langkahpemecahan-masalah/)

Berdasarkan pendapat diatas, dapat disimpulkan bahwa langkahlangkah pemecahan masalah adalah (1) pemahaman masalah, (2) merencanakan pemecahan masalah, (3) melaksanakan rencana pemecahan masalah, (4) menemukan jawaban dan meneliti kembali hasilnya, (5) mengaplikasikan jawaban/ generalisasi yang diperoleh ke situasi baru

\section{Metodologi Penelitian}

Penelitian ini dilaksanakan di MTs Negeri Caruban jl. Penanggungan 02 Caruban Kab. Madiun. Penelitian ini dilaksanakan pada semester genap tahun pelajaran 2012/2013 pada bulan april 2013. Penelitian ini adalah penelitian kualitatif, karena hasil laporan penelitian berupa kata-kata atau kalimat dan bukan berbentuk statistik serta dalam mendapatkan informasi diperoleh dari keadaan sewajarnya yang masih asli. Dalam penelitian ini subyek penelitiannya adalah siswa kelas VIII MTs Negeri Caruban Kab. Madiun tahun pelajaran 2012/2013. Berdasarkan rekomendasi guru, dari lima kelas yang dipilih kelas VIII E dengan diambil sebanyak 6 anak. Dari ke-6 subyek tersebut dibagi berdasarkan kriterianya. Untuk kriteria tinggi adalah subyek 1 dan subyek 2, untuk kriteria sedang adalah subyek 3 dan subyek 4, sedangkan untuk kriteria rendah adalah subyek 5 dan subyek 6. Metode pengumpulan data yang diperlukan dalam penelitian ini adalah metode observasi, metode tes, metode 
wawancara, dan dokumentasi. Dalam penelitian ini, teknik pemeriksaan keabsahan suatu data akan dilakukan melalui trianggulasi data. Triangulasi sumber disebut juga dengan triangulasi data. Cara ini mengarahkan peneliti agar di dalam mengumpulkan data, ia wajib menggunakan beragam sumber data yang tersedia. Penelitian ini merupakan penelitian kualitatif, maka analisis datanya adalah non statistik. Data muncul barupa kata-kata dan bukan merupakan rangkaian angka. Dalam penelitian ini, data diambil dari hasil tes. Berdasarkan jawaban siswa kemudian dianalisis tahap-tahap atau langkahlangkah yang dilakukan oleh siswa. Data hasil tes, data dari wawancara, data hasil observasi dibandingkan untuk mendapatkan data yang valid, kemudian dilakukan reduksi data, yaitu proses pemilihan, pemusatan perhatian pada penyederhanaan, pengabstrakan dan transformasi data-data kasar dari catatan di lapangan. Proses reduksi data bertujuan untuk menghindari penumpukan data/informasi dari siswa, kemudian data yang telah valid disajikan untuk tiap jawaban dan faktor-faktor apa yang menjadi penyebabnya.

\section{Hasil Penelitian}

Dari hasil tes yang diberikan kepada siswa kelas VIII E MTs Negeri Caruban, peneliti dapat menyelidiki dan menganalisis kesalahan siswa berdasarkan pekerjaan siswa yang mengacu pada letak kesalahan yang dialami siswa. Tes dilaksanakan pada tanggal 30 April 2013.Tes uraian tersebut ditujukan kepada keenam subyek yang telah ditunjuk sesuai kriterianya. Kesalahan tersebut ditinjau dari indikator dan deskriptor kesalahan siswa yang disajikan pada tabel berikut.

\begin{tabular}{ccccccccc}
\hline $\begin{array}{c}\text { (S) Subyek } \\
(1)\end{array}$ & 2) & 3) & 4) & 5) & 6) & 7) & 8) & 9) \\
\hline 1 & A1 & B1 & IA1 & IB1 & IC1 & IIB1 & VA1 & VB1 \\
2 & A1 & B1 & IA1 & IB1 & IC1 & IIB1 & VA1 & VB1 \\
3 & A1 & B1 & IA1 & IB1 & IC1 & IIB1 & VA1 & VB1 \\
4 & A2 & B1 & IA3 & IB2 & IC2 & IIB1 & VA3 & VB3 \\
5 & A2 & B3 & IA3 & IB2 & IC3 & IIB2 & VA3 & VB3 \\
6 & A3 & B2 & IA3 & IB2 & IC3 & IIB3 & VA3 & VB3 \\
\hline
\end{tabular}

Tabel. 1. Indikator dan Deskriptor Kesalahan Siswa Kelas VIII E

Keterangan :

Pada kolom (2) terlihat bahwa, dalam tahap perencanaan penyelesaian masalah terdapat kesalahan yang berbeda, subyek tinggi mempunyai kecenderungan terhadap kode IA1, berarti pada kesalahan menginterprestasi bahasa subyek cenderung tidak mengalami kesalahan dalam memahami maksud soal. Sedangkan subyek sedang dan subyek rendah peneliti belum bisa menyimpulkan secara umum.

Pada kolom (3) terlihat bahwa, dalam tahap perencanaan penyelesaian masalah terdapat kesalahan yang berbeda, subyek tinggi dan subyek sedang mempunyai kecenderungan terhadap kode IB1, berarti pada kesalahan menginterprestasi bahasa subyek cenderung tidak mengalami kesalahan dalam menerjemahkan soal dari bahasa umum 
ke model matematika. Sedangkan subyek rendah peneliti belum bisa menyimpulkan secara umum.

Pada kolom (4) terlihat bahwa, dalam tahap perencanaan penyelesaian masalah terdapat kesalahan yang berbeda, subyek tinggi mempunyai kecenderungan terhadap kode IIA1, berarti pada kesalahan konsep subyek cenderung tidak mengalami kesalahan menerapkan konsep dalam menyelesaikan soal. Sedangkan subyek rendah mempunyai kecenderungan terhadap IIA3, berarti pada kesalahan konsep subyek cenderung mengalami kesalahan menerapkan konsep dalam menyelesaikan soal.Subyek sedang peneliti belum bisa menyimpulkan secsra umum.

Pada kolom (5) terlihat bahwa, dalam tahap perencanaan penyelesaian masalah terdapat kesalahn yang berbeda, subyek tinggi mempunyai kecenderungan terhadap kode IIB1, berarti pada kesalahan konsep subyek tidak mengalami kesalahan menerapkan rumus dalam menyelesaikan soal. Sedangkan subyek rendah mempunyai kecenderungan terhadap IIB2, berarti pada kesalahan konsep subyek cenderung mengalami kesalahan menerapkan rumus dalam menyelesaikan soal. Pada subyek sedang peneliti belum bisa menyimpulkan secara umum.

Pada kolom (6) terlihat bahwa, dalam tahap perencanaan penyelesaian masalah terdapat kesalahan yang berbeda, subyek tinggi mempunyai kecenderungan terhadap kode IIC1, berarti pada kesalahan konsep subyek cenderung tidak mengalami kesalahan prosedur pengerjaan soal. Sedangkan untuk subyek rendah mempunyai kecenderungan terhadap kode IIC3, berarti pada kesalahan konsep subyek cenderung mengalami kesalahan prosedur pengerjaan soal. Pada subyek sedang peneliti belum bisa menyimpulkan secara umum.
Pada kolom (7) terlihat bahwa, dalam tahap perencanaan penyelesaian masalah terdapat kesalahan yang berbeda, subyek tinggi dan subyek sedang mempunyai kecenderungan terhadap kode IIIB1, berarti pada kesalahan teknis subyek cenderung tidak mengalami kesalahan dalam melakukan operasi hitung. Subyek tinggi dan subyek sedang benar dalam melakukan perhitungan (penjumlahan, pengurangan, perkalian, dan pembagian). Pada subyek sedang dan subyek rendah peneliti belum bisa menyimpulkan secara umum.

Pada kolom (8) terlihat bahwa, dalam tahap perencanaan penyelesaian masalah terdapat kesalahan yang berbeda, subyek tinggi mempunyai kecenderungan terhadap kode IVA1, berarti pada kesalahan kealpaan subyek cenderung tidak mengalami kesalahan menyelesaikan soal dengan benar. Sedangkan subyek rendah mempunyai kecenderungan terhadap IVA3, berarti pada kesalahan kealpaan subyek cenderung mengalami kesalahan menyelesaikan soal dengan benar. Pada subyek sedang peneliti belum bisa menyimpulkan secara umum.

Pada kolom (9) terlihat bahwa, dalam tahap perencanaan penyelesaian masalah terdapat kesalahan yang berbeda, subyek tinggi mempunyai kecenderungan terhadap kode IVB1, berarti pada kesalahan kealpaan subyek cenderung cermat terhadap jawaban. Sedangkan subyek rendah mempunyai kecenderungan terhadap IVB3, berarti pada kesalahan kealpaan subyek cenderung tidak cermat terhadap jawaban Pada subyek sedang peneliti belum bisa menyimpulkan secara umum.

\section{KESIMPULAN DAN SARAN Kesimpulan}

Berdasarkan analisis data penelitian dan pembahasan kesalahankesalahan yang dilakukan siswa MTs kelas VIII E dalam menyelesaikan soal uraian matematika pada pokok bahasan 
unsur-unsur lingkaran maka dapat diambil kesimpulan sebagai berikut.

Kesalahan menginterprestasi bahasa

Siswa dengan kemampuan matematika tinggi dan sedang cenderung tidak mengalami kesalahan dalam memahami maksud soal. Siswa dapat memahami soal dengan baik serta paham terhadap permintaan soal.

Siswa dengan kemampuan matematika tinggi dan sedang cenderung tidak mengalami kesalahan dalam menerjemahkan soal dari bahasa umum ke model matematika. Siswa dapat menggunakan simbol-simbol matematika dengan benar dalam membentuk model matematika dari soal. Kesalahan konsep

Siswa dengan kemampuan matematika tinggi cenderung tidak mengalami kesalahan dalam menerapkan konsep, sedangkan siswa dengan kemampuan matematika rendah cenderung mengalami kesalahan dalam menerapkan konsep.

Siswa dengan kemampuan matematika tinggi cenderung tidak mengalami kesalahan dalam menerapkan rumus, sedangkan siswa dengan kemampuan rendah cenderung mengalami kesalahan dalam menerapkan rumus.

Siswa dengan kemampuan matematika tinggi. Sedangkan siswa dengan kemampuan matematika rendah cenderung mengalami kesalahan dalam menentukan prosedur pengerjaan soal.

Kesalahan teknis

Siswa dengan kemampuan matematika tinggi dan sedang cenderung tidak mengalami kesalahan dalam melakukan operasi hitung, sedangkan siswa dengan kemampuan matematika rendah cenderung mengalami kesalahan dalam melakukan operasi hitung.

Kesalahan kealpaan

Siswa dengan kemampuan matematika tinggi cenderung tidak mengalami kesalahan dalam menyelesaikan soal. Sedangkan siswa dengan kemampuan matematika rendah cenderung mengalami kesalahan dalam menyelesaikan soal.

Siswa dengan kemampuan matematika tinggi cenderung tidak mengalami kesalahan dalam kecermatan meneliti hasil pekerjaannya, sedangkan siswa dengan kemampuan matematika rendah cenderung mengalami kesalahan dalam kecermatan meneliti hasil pekerjaannya.

\section{Saran}

Berdasarkan kesimpulan, untuk mengatasi kesalahan-kesalahan yang dilakukan siswa MTs dalam menyelesaikan soal uraian matematika pada pokok bahasan unsur-unsur lingkaran maka dapat disarankan sebagai berikut. 1) Bagi siswa diharapkan siswa dapat meminimalisisr kesalahan yang dilakukan dalam menyelesaikan soal uraian matematika pada pokok bahasan unsur-unsur lingkaran. 2) Bagi guru diharapkan guru dapat memberikan banyak latihan dan bimbingan dalam menyelesaikan soal uraian, agar siswa bisa meminimalisir kesalahan dalam menyelesaikan soal uraian matematika pada pokok bahasan unsur-unsur lingkaran. 3) Bagi peneliti lain diharapkan peneliti lain dapat melakukan penelitian dengan sampel yang lebih banyak lagi agar bisa mendapatkan kesimpulan yang akurat, karena semakin banyak sampel yang diteliti maka hasil penelitian akan lebih akurat.4) Kelemahan dalam penelitian ini yaitu peneliti belum bisa menyimpulkan secara umum kesalahan siswa yang berbeda pada kategori yang sama, karena terdapat perbedaan antara subyek satu dengan yang lain, yaitu pada tahap pemahaman masalah dengan subyek kemampuan matematika tinggi cenderung tidak mengalami kesalahan dalam memahami maksud soal sedangkan subyek dengan kemampuan rendah peneliti belum bisa menyimpulkan secara umum karena terdapat perbedaan kesalahan. Begitu 
juga pada tahap menemukan jawaban dan meneliti kembali hasilnya yaitu subyek dengan kemampuan rendah peneliti belum bisa menyimpulkan secara umum. 5) Keterbatasan dalam penelitian ini yaitu terbatasnya waktu penelitian karena siswa kelas VIII akan melaksanakan ujian kenaikan kelas sehingga lebih fokus terhadap materi yang pada saat itu belum selesai diberikan oleh guru mata pelajaran. Maka dari itu waktu yang diberikan oleh pihak sekolah terbatas.

\section{DAFTAR PUSTAKA}

Basrowi dan Suwandi. 2008. Memahami Penelitian Kualitatif. Jakarta : Rineka Cipta.

Darmadi. 2009. Pengaruh Pemanfaatan Powerpoint dalam Pembelajaran terhadap Prestasi Matematika Tingkat Sekolah Dasar Ditinjau dari Gaya Belajar Siswa. Jurnal Pendidikan IKIP PGRI Madiun.

Dimyati dan Mudjiono. 2009. Belajar dan Pembelajaran. Jakarta: PT Rineka Cipta.

Emzir. 2012. Metodologi Penelitian Kualitatif Analisis Data. Jakarta : PT Rajagrafindo Persada.

Hamzah B. Uno. 2007. Model Pembelajaran Menciptakan Proses Belajar yang Kreatif dan Efektif. Jakarta: Bumi Aksara.

Herman Hudojo. 2005. Pengembengan Kurikulum dan Pembelajaran Matematika. Malang: UM Press.
Krisyanto. Langkah-Langkah

Pemecahan Masalah. (online) (http://krizi.wordpress.com/2011/ 09/12/makalah-matematika-

langkah-langkah-pemecahanmasalah/, diakses 12 Maret 2013)

Mahi. M. Hikmat. 2011. Metode Penelitian : Dalam Prespektif Ilmu Komunikasi dan Sastra. Yogyakarta : Graha Ilmu.

Muhibbin Syah. 2009. Psikologi Belajar. Jakarta: PT Rajagrafindo persada.

Mulyono Abdurrahman. 2012. Anak Berkesulitan Belajar. Jakarta: PT Rineka Cipta.

Sardulo Gembong dan Sanusi. 2007. Kesulitan-Kesulitan yang Dihadapi Guru dan Siswa Sekolah Dasar dalam Pembelajaran Matematika dengan Kurikulum Berbasis Kompetensi. Jurnal Pendidikan IKIP PGRI Madiun.

Slameto. 2010. Belajar dan Faktorfaktor yang Mempengaruhinya. Jakarta: Rineka Cipta.

Sugiyono. 2007. Metode Penelitian Kuantitatif, Kualitatif dan $R \& D$. Bandung: CV Alfabeta.

2012. Metode Penelitian Kuantitatif, Kualitatif dan $R \& D$. Bandung: CV Alfabeta.

Suharsimi Arikunto. 2012. Dasar-Dasar Evaluasi Pendidikan. Jakarta: PT Rineka Cipta.

Syaiful Bahri Djamarah. 2002. Psikologi Belajar. Jakarta: PT Rineka Cipta. 